\title{
Analysis of Effect of ZIS (Zakat, Infaq, And Shadaqah), Regional Domestic Products of Bruto, Regional Minimum Wage and Inflation on Levels Poverty in Indonesia 2012 - 2016
}

\author{
Fiky Nila Mustika ${ }^{1}$, Eni Setyowati ${ }^{2}$, Azhar Alam ${ }^{3}$ \\ ${ }^{1}$ Faculty of Islamic Studies, Universitas Muhammadiyah \\ Surakarta \\ email: fikynila@gmail.com \\ ${ }^{2}$ Faculty of Economics and Business, Universitas \\ Muhammadiyah Surakarta \\ email: es241@ums.ac.id \\ ${ }^{3}$ Faculty of Islamic Studies, Universitas Muhammadiyah \\ Surakarta \\ email: aa123@ums.ac.id
}

\begin{abstract}
This study investigated the impact of ZIS (Zakat, Infaq, and Sadaqah) Gross Regional Domestic Products, Regional Minimum Wages, and Inflation on Poverty Levels in Indonesia during the 2012-2016 period. .This paper used secondary data in the panel data form. This research conducted a quantitative approach using panel data regression. Based on the results of the panel data testing, the best model chosen is the Random Effect Model (REM). Variables of gross regional domestic products and regional minimum wages have a significant effect on poverty levels in Indonesia while the variables of zakat, infaq, and shadaqah (ZIS) and inflation do not influence the level of poverty in Indonesia.
\end{abstract}

Keywords: ZIS (Zakah, Infaq, Sadaqa), Gross Regional Domestic Products, Regional Minimum Wages, Poverty 


\section{INTRODUCTION}

Poverty for Indonesia several other developing countries is still a significant problem. This poverty problem is very complex and related to economic aspects. Poverty becomes a significant obstacle and is very calculated by a country in the process of fixing various problems in that country (Ihsan and Ikshan, 2018).

Poverty arises due to differences in abilities, differences in opportunities, and differences in resources. Poverty was allegedly able to cause various social crimes and unkindness. Poor people are not able to carry out religious obligations to the fullest as people who are not poor, are less able to carry out social functions, cannot access good education, a decent life, quality health care (Maipita, 2014). (Maipita, 2014).

Poverty impedes people because of limited funds, difficulties in obtaining an education, health, and the necessities of a decent life. Poverty is a very serious problem and requires an important role from various parties so that it can help the government in poverty alleviation efforts in Indonesia. The poverty rate must be reduced in order to increase and overall community welfare. Poverty reduction is the main objective of development policy throughout the world. This is also the main objective of Islamic economics and institutions, especially zakat institutions. Effective poverty reduction strategies must be designed and implemented. This perspective also applies to zakat institutions because Muslims generally believe that zakat is a real Islamic institution to combat the problem of poverty (Kasri, 2017).

Poverty alleviation and reducing income inequality deserve priority in national economic development strategies. The only way to solve problems is to use instruments based on local culture or religion. In this case, the zakat institution is considered as one of the most effective traditional mechanisms for dealing with the problem of poverty (Ayuniyyah, Pramanik and Ariffin, 2018)

Zakat is an obligation for every Muslim whose wealth when it has reached the minimum value called nisaab. Poverty alleviation and economic empowerment are some of the main objectives of zakat. Zakat plays a unique role because it is the only one that 
connects the payer with the hands of the recipients of the poor intending to reduce their poverty and empower them(Kareem and Bankole, 2016).

Gross Regional Domestic Product, according to Hamrolle (2004), is the value of the entire production of goods and services produced by certain people (in a certain period of time) / 1 year. GRDP is an indicator to regulate the extent to which the success of the government in utilizing existing resources and can be used as a plan and decision making, one of which is to reduce the amount of poverty.

Minimum wages are directed at achieving the needs of a decent life by paying attention to productivity and economic growth. Wages are a source of income, if the source of income decreases or remains, then welfare also decreases or remains, and it also will certainly affect the level of poverty (Ningrum, 2017).

Rising production costs can trigger inflation through rising output prices, lowering purchasing power, reducing exports, reducing output, reducing economic growth, and increasing poverty rates, although sometimes high growth is also accompanied by high levels of poverty (Maipita, 2012).

This study tried to give an illustration of the influence of ZIS Distribution ZIS (Zakat Infaq, and Sadaqah), Gross Domestic Product, Minimum Wage, and inflation on Indonesia poverty level. This research is expected to provide additional insights into the field of Islamic economics, especially about the study of Islamic macroeconomics and monetary. Besides that, this research can also be used to add research field experience and discussion of the policymaker to overcome the problem of poverty.

\section{LITERATURE REVIEW}

\section{Effects of Zakat, Infaq, and Sadaqah (ZIS) on Poverty}

Zakat is one component in the Islamic welfare system. Aside from being a means to purify lives and property, zakat is also a tip for guaranteeing the protection, development, and regulation of the distribution and distribution of wealth.

Utilization and distribution of zakat funds so far have experienced many obstacles, especially the distribution of zakat 
related to productive zakat products. Zakat distribution is still a problem and one of inefficiency source for Zakat institutions(Alam, 2018). The distribution has to be made in more productive and creative ways to stimulate the poor economy.

Zakat, Infaq, and Sadaqah are sources of state revenue. One of the efforts in reducing poverty in Indonesia is to do income distribution between the able and the poor. Zakat is one of the efforts to distribute income to the poor. Zakat purifies the soul from stinginess, greed, and selfishness and it has a positive impact on the economy of the community by reducing poverty and increasing economic growth (Canggih, Fikriyah, and Yasin, 2017)

Zakat is also able to influence the economic policies of the Islamic government to improve the welfare of the people, especially the weak. In the structure of the conventional fiscal policy, zakat is not yet one of the instruments. The implementation of zakat so far is more an activity of the people who want to purify their wealth. The collection and distribution are done traditionally and not in the productive form. As a result, zakat was made to deal with the poverty levels that plagued Muslim countries, including Indonesia.

The basic principles of Islam about development with all its aspects, especially the problem of economic development is an interesting thing to be studied more deeply because on the one hand it is hoped to be able to solve the economic problems that have plagued the world throughout time with complete Islamic teachings.

Zakat, infaq and shadaqah (ZIS) can actually be used as a means of poverty alleviation because they can reduce income disparities between classes in society, as well as can be a door for the creation of motivation in the real sector, if the management of Zakat, infaq, and shadaqah (ZIS) is directed at a form that is directed more productive (Yusuf, et al., 2014).

Zakat has a strategic role in efforts to reduce poverty or economic development. In contrast to other financial sources for development, zakat does not have any backlash except s merit expectation from Allah SWT alone. However, it does not mean 
the mechanism of zakat does not have a control system. If the value of Zakat, Infaq and Sadaqah increases, it will increase the welfare of the community so that the community will prosper and the number of poor people decreases

\section{Effect of Gross Regional Domestic Product on Poverty}

Gross Regional Domestic Product (GRDP) is one indicator to determine the performance of development, primarily regional economic development. Gross Regional Domestic Product (GRDP) is the amount of added value created from all the economic activities in an area without regard to the owner of production factors. GRDP illustrates the ability of an area to manage natural resources and human resources to create added value. Thus, the availability of crackers, both physical and non-physical, is one of the factors that determine the amount of GRDP.

Gross Regional Domestic Product is used to measure the rate of economic growth. Economists believe that the best way to pursue economic backwardness is to increase the rate of economic growth as high as possible so that it can surpass the rate of population growth. In this way, the per capita income figure will increase so that there will automatically be an increase in community prosperity. The development process requires high national income and many countries the main condition for creating a permanent poverty reduction is economic growth.

Economic growth is not enough to alleviate poverty, but economic growth is usually something that is needed, even though good economic growth will not be meaningful for the decline of the poor if it is not accompanied by equitable distribution of income. Economic growth is an indicator to see the success of development and is a must for poverty reduction. The condition of sufficiency is that economic growth is effective in reducing poverty. That is, the growth should spread in each income group, including the poor population.

Gross Regional Domestic Product is generated income through goods and services by all economic activities in a region within a specified period. The higher the Gross Regional Domestic Product in an area, the higher the level of revenue of the region, 
but the Gross Regional Domestic Product does not guarantee that all residents enjoy prosperity. Gross Regional Domestic Product is only a general description of the welfare of the community. The increase in Gross Regional Domestic Product cannot be concluded whether the condition of the low-income population has improved or not(Sudiana and Sudiana, 2015). Lack of capital, low levels of education, traditional economic activities with low productivity and rapid population growth have hampered efforts to accelerate development so that the state of poverty can not be eliminated (Sukirno, 2008)

\section{Effects of Regional Minimum Wages on Poverty}

One of the goals of national development is to improve economic performance to be able to create jobs and organize a decent life for all people, which in turn will bring prosperity to the population in a country. The efforts made by the government in terms of poverty alleviation are earnest; it can be seen in terms of the many programs run by the government. Many macroeconomic variables can be used as a cause of increasing or decreasing poverty in an area, including Regional Minimum Wages (Sari and Mangkuwinata, 2017).

In general, the review of minimum wages can be viewed from three sides, namely from the side of workers, companies, and the government. From the worker side, wages become an obligation to finance the needs of life for themselves and their families. Wages are also a motivation for workers in the productivity of their work. From the company side, wages are a deduction from profits, because wages are a cost factor that must be incurred by the company in the production process. Moreover, from the government side, wages become a means to create equitable income and improve community welfare(Ihsan and Ikshan, 2018) (Ihsan et al., 2018).

The minimum wage is an attempt to raise the level of the lowincome population, especially poor workers. The minimum wage is a minimum standard used by employers or industry players to provide wages to workers in a business or work environment. The main objective of setting minimum wages is to meet minimum 
living standards such as for the health, efficiency, and welfare of workers (Sari and Mangkuwinata, 2017).

Wages are a source of income, if the source of income decreases or remains, then welfare also decreases or stays, and it also will affect the level of poverty (Ningrum, 2017)

\section{Influence of Inflation on Poverty}

Inflation is the tendency for prices of goods to rise continuously. An increase in the prices of goods is comprehensive if only a few types of goods are not said to be inflation unless the increase in the price of one item extends and results in an increase in other goods. High inflation causes a decrease in the real income of people who have a fixed income, can also reduce the value of public wealth such as savings in banks and owned cash (Ihsan and Ikshan, 2018)

The relationship between inflation and poverty can be explained in two ways. First, inflation causes the real value of money held to go down. When prices increase, purchasing power goes down. Second, inflation causes the real interest earned from saving money in banks to decrease so that purchasing power decreases. This decline in purchasing power has resulted in people becoming more impoverished than before. Inflation affects the income of the community and company households because of the weak purchasing power of the community (Sari and Mangkuwinata, 2017).

There is a very close relationship between high inflation and poverty because people want to live beyond their economic capabilities. There is a struggle for the fortune section among social groups who want more than what is already available or obtained by the community. Inflation can drive income redistribution. This will affect people's welfare because the redistribution of income that occurs will cause the real income of one community to increase and the real income of other people to fall.

\section{Review of Related Research}

Mahendra (2016) concluded that economic growth, per capita income, inflation, and unemployment during the period 2003 to 2014 did not have a significant simultaneous effect on the number of poor people in North Sumatra at a significance level of 5\%. Thus 
the research hypothesis was rejected; Based on the partial test $(\mathrm{t}$ test), the variables of economic growth, income per capita, inflation and unemployment did not significantly affect the variable number of poor people in North Sumatra by testing at a $95 \%$ confidence level.

Susanto, Rochaida, and Ulfah (2018) found that Inflation has an indirect and insignificant effect on poverty in Samarinda City. Susanto, Rochaida, and Ulfah (2018) explained that there was a simultaneous influence of GRDP, education, and agricultural labor structure on poverty levels in Bali Province. The t test shows that there is a negative but significant influence on the level of poverty in the Province of Bali, while the agricultural labor structure is partially influential but not significant to poverty in the Province of Bali.

Ihsan and Ikshan (2018) stated that minimum wage has a positive and significant effect on poverty, inflation has a positive but not significant effect on poverty, while the amount of unemployment is negatively and significantly related to poverty in Aceh province. Andria, Hamzah, and Nasir (2014) explained that the GDP per capita, unemployment, and inflation together have a significant effect on the number of poor people in Aceh Province.

Hassanain (2017) found there is a positive and significant relationship between the Zakat System program in the Republic of Sudan and poverty alleviation in Sudan. Zakat also is indicated to have a positive and significant relationship between the Zakat System program in the Republic of Sudan and poverty alleviation in Sudan (Kareem and Bankole, 2016).

Abdussalam, Johari, and Alias (2015) stated that zakat and its institutions were not significantly and effectively in reducing poverty among poor Muslims in Kwara State, Nigeria. However, recommendations are made towards the introduction of zakat standards institutions in the State to help in poverty alleviation among poor Muslims

Ayuniyyah, Pramanik, and Ariffin (2018) found that in general, the current zakat distribution program can reduce poverty and reduce income inequality among the recipients of zakat 
observed. Kasri (2017) concluded that the incidence, depth, and severity of poverty between recipients had decreased along with the contribution made by the zakat management organization. A group of people who have a lower age, lower education, less formal employment, smaller household sizes, and non-economic charity assistance should be the main target of zakat intervention in Indonesia (Kasri, 2016). Other study concluded that the distribution of ZIS funds had a significant adverse effect on MSME growth and GRDP growth in East Java. The distribution of IFI funds has a significant positive effect on MSME growth and GDRP growth in East Java. (Hamidah et al., 2017)

\section{METHODS}

This paper used panel data from 34 provinces in Indonesia during 2012-2016. The data sources of this research are the Central Statistics Agency, the National Amil Zakat Agency, and others. This paper conducted two kinds of variable, dependent, and independent. The dependent variable in this study is poverty (Y) while The independent variable consists of Zakat, Infaq, and Sadaqah $\left(\mathrm{X}_{1}\right)$, Gross Regional Domestic Product $\left(\mathrm{X}_{2}\right)$, Regional Minimum Wage $\left(\mathrm{X}_{3}\right)$, and Inflation $\left(\mathrm{X}_{4}\right)$.

This research used a panel data regression model to analyze quantitatively and estimate the effect of several independent variables simultaneously or partially on the dependent variable. The model used in this study is a modification of a research journal conducted by Ihsan and Ikshan (2018)

$$
K M_{i t}=\beta_{0}+\beta_{1} Z I S_{i t}+\beta_{2} G R D P_{i t}+\beta_{3} R M W_{i t}+\beta_{4} I N F_{i t}+u_{i t}
$$

Where:

$$
\begin{array}{ll}
\text { KM } & =\text { Poverty for the } \mathrm{i} \text {-th region and } \mathrm{t} \text {-time } \\
\beta_{0} & =\text { Intercept coefficient which is a scalar } \\
\text { ZIS } & =\text { Zakat, Infaq, Sadaqah for the } \mathrm{i} \text {-th region and t-time } \\
\text { GRDP } & =\text { Gross Regional Domestic Product for the } \mathrm{i} \text { region } \\
& \text { and } \mathrm{t} \text {-time } \\
\text { RMW } & =\text { Regional Minimum Wage for the } \mathrm{i} \text {-th region and }
\end{array}
$$




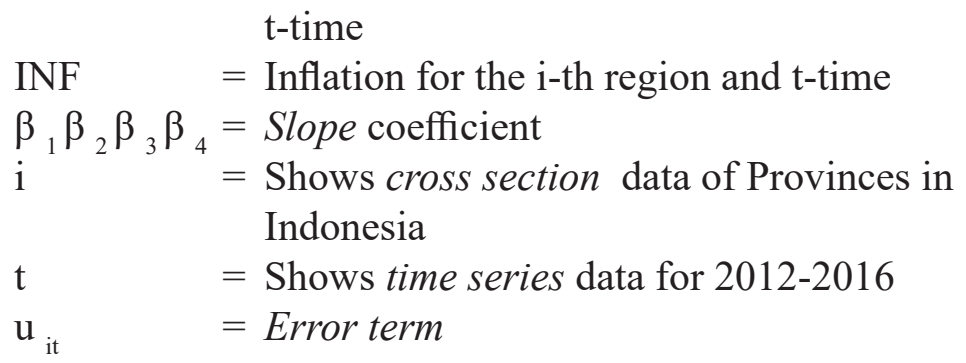

\section{Research Framework}

This paper used framework as described below :

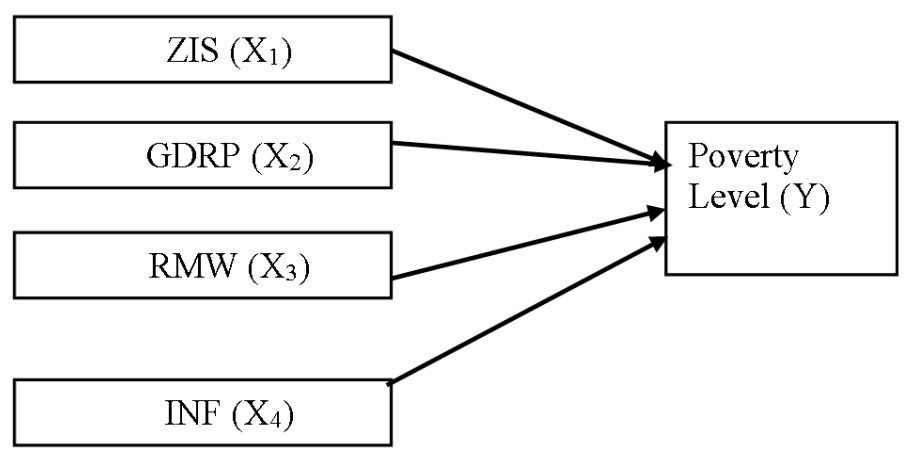

Source: Ihsan and Ikshan (2018)

\section{Graph 1. Research Framework}

The framework of this research is that poverty is influenced by four variables, namely ZIS (Zakat Infaq, and Sadaqah), Gross Regional Domestic Product, Regional Minimum Wage, and Inflation. This paper also designed the hypothesis as follows:

1. Zakat, Infaq, and Sadaqah (ZIS) have a significant effect on poverty levels.

2. Gross Regional Domestic Product significantly influences the Poverty levels

3. Regional Minimum Wage has a significant effect on poverty levels.

4. Inflation does not affect poverty levels 


\section{RESULTS AND DISCUSSION}

The estimation results of Panel Data Regression is described through the Pooled Ordinary Least Square (PLS) approach, Fixed Effect Model (FEM), and Random Effecet Model (REM) as can be seen in Table 1

Table 1. Cross Panel Regression Results

\begin{tabular}{lccc}
\hline \multirow{2}{*}{ Variable } & \multicolumn{3}{c}{ Regression Coefficient } \\
\cline { 2 - 4 } & PLS & FEM & REM \\
\hline C & 13,51388 & 12.78654 & 12.50397 \\
ZIS & $-5.54 \mathrm{E}-11$ & $4.97 \mathrm{E}-12$ & $2.60 \mathrm{E}-12$ \\
GRDP & $-1.96 \mathrm{E}-06$ & $-6.72 \mathrm{E}-06$ & $-5.45 \mathrm{E}-06$ \\
UMR & $3.52 \mathrm{E}-07$ & $4.86 \mathrm{E}-07$ & $4.71 \mathrm{E}-07$ \\
INF & -0.259820 & -0.018208 & -0.018407 \\
& 0.072392 & 0.986789 & 0.076193 \\
Adj. & 0.049905 & 0.983086 & 0.053798 \\
F-statistics & 3.219232 & 266.4792 & 3.402181 \\
Prob F-Statistics & 0.014156 & 0.000000 & 0.010542 \\
\hline
\end{tabular}

Source: processed data

\section{Panel Data Model Selection Test}

To determine the best estimation model from PLS, FEM, and $R E M$ estimation results, the Chow test and Hausman test are used.

Chow test is a test used to determine whether the FEM model is better than the PLS model. The results of processing Chow Test can be seen in Table 2 below

Table 2. Results of Panel Data Estimation Using Chow Test

\begin{tabular}{lccc}
\hline \multicolumn{1}{c}{ Effects Test } & Statistic & d.f. & Prob. \\
\hline Cross-section F & 276.860747 & $(33,132)$ & 0.0000 \\
Cross-section Chi-square & 722.765986 & 33 & 0.0000 \\
\hline
\end{tabular}

Source: Data processed

Table 2 depicted that the p-value or probability $\mathrm{F}$ test at 0 , $0000 \leq$ alpha (0.05) and Chi-Squared by $0,0000 \leq$ alpha (0.05) then the chosen model would be a fixed-effect model (FEM). 
The Hausman test is a test used to see whether the FEM model is better than the REM model. The results of processing the Hausman Test can be seen in Table 3 below

Table3. Results of Panel Data Estimation Using Hausman Test

\begin{tabular}{cccc}
\hline Test Summary & Chi-Sq. Statistic & Chi-Sq. d.f. & Prob. \\
\hline Cross-section random & 4.493161 & 4 & 0.3434 \\
\hline
\end{tabular}

Source: Data processed

If the p-value or probability of the Chi-Squared statistic or random cross-section is $0,3434>\alpha(0.05)$, then the conclusion is using a random effect model. Based on the results of the panel data estimation, the best-chosen model is the Random Effect Model (REM).

\section{Analysis of Random Effect Model Estimation Results}

Random Effect Model (REM) Results can be seen in Table 4 and five below:

Table 4. Random Effect Model Estimation Results

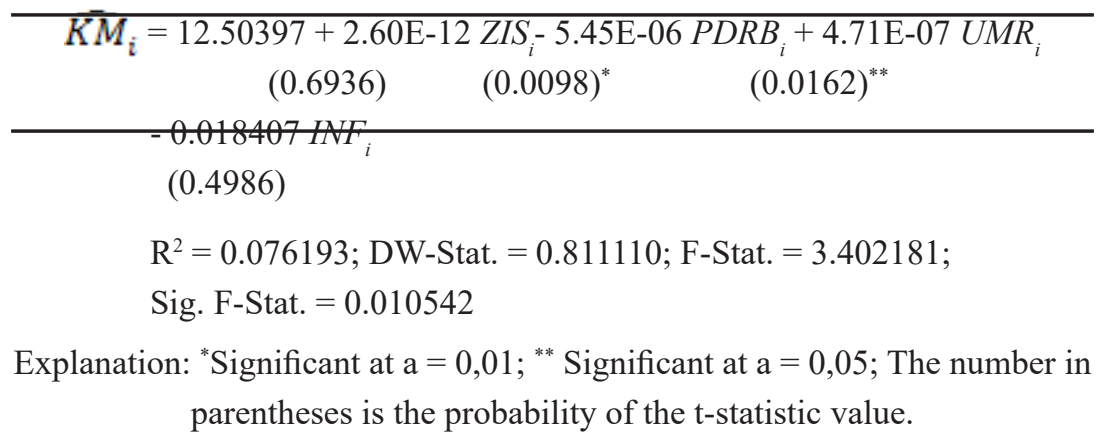

The coefficient of determination shows the full capacity of the selected statistical model. Based on Table 4 the result indicates the $R^{2}$ of 0.076193 , it means that $7.61 \%$ of poverty level variable variation can be explained by a variety of variables including Zakat, infaq, and sadaqah (ZIS), regional gross domestic product, regional minimum wages, and inflation while the remaining 92.39 
$\%$ are influenced by variations of other variables not included in the model.

Variable gross regional domestic product has a regression coefficient of $-5.45 \mathrm{E}-06$, and the pattern of the relationship of poverty level with the gross regional domestic product is linear, meaning that if the gross regional domestic product variable rises 1 billion, the poverty rate will decrease by $0.00000545 \%$.

Local minimum wage variable has a regression coefficient of $4.71 \mathrm{E}-07$, and the pattern of the relationship of poverty level with regional minimum wage is linear, meaning that if the regional minimum wage variable rises Rp. $1,000,000.00$ then the poverty rate will rise by $0.471 \%$.

Table 5. Random Effect Model Estimation Results

\begin{tabular}{clrr}
\hline No & \multicolumn{1}{c}{ Province } & \multicolumn{1}{c}{ Effects } & \multicolumn{1}{c}{ Constant } \\
\hline 1 & ACEH & 4.922164 & 17.426134 \\
2 & SUMATERA UTARA & -0.54464 & 11.959327 \\
3 & SUMATERA BARAT & -4.91842 & 7.585546 \\
4 & RIAU & -2.65311 & 9.850856 \\
5 & JAMBI & -4.03525 & 8.468722 \\
6 & SUMATERA SELATAN & 1.87544 & 14.37941 \\
7 & BENGKULU & 4.707711 & 17.211681 \\
8 & LAMPUNG & 2.53305 & 15.03702 \\
9 & KEP. BANGKA BELITUNG & -7.69056 & 4.813413 \\
10 & KEP. RIAU & -5.99585 & 6.508119 \\
11 & DKI JAKARTA & -2.49715 & 10.006823 \\
12 & JAWA BARAT & 2.76339 & 15.26736 \\
13 & JAWA TENGAH & 5.495696 & 17.999666 \\
14 & DI YOGYAKARTA & 2.294646 & 14.798616 \\
15 & JAWA TIMUR & 6.574819 & 19.078789 \\
16 & BANTEN & -5.48637 & 7.017597 \\
17 & BALI & -7.95319 & 4.55078 \\
18 & NUSA TENGGARA BARAT & 4.652462 & 17.156432 \\
19 & NUSA TENGGARA TIMUR & 8.357469 & 20.861439 \\
20 & KALIMANTAN BARAT & -4.20967 & 8.294302 \\
21 & KALIMANTAN TENGAH & -6.79957 & 5.704401 \\
\hline & & &
\end{tabular}




\begin{tabular}{llcr}
\hline No & \multicolumn{1}{c}{ Province } & Effects & \multicolumn{1}{c}{ Constanta } \\
\hline 22 & KALIMANTAN SELATAN & -7.73881 & 4.765156 \\
23 & KALIMANTAN TIMUR & -4.54356 & 7.960415 \\
24 & KALIMANTAN UTARA & -9.95253 & 2.551436 \\
25 & SULAWESI UTARA & -4.54927 & 7.954704 \\
26 & SULAWESI TENGAH & 1.822393 & 14.326363 \\
27 & SULAWESI SELATAN & -2.17658 & 10.327393 \\
28 & SULAWESI TENGGARA & 0.543616 & 13.047586 \\
29 & GORONTALO & 4.706353 & 17.210323 \\
30 & SULAWESI BARAT & -0.72372 & 11.78025 \\
31 & MALUKU & 6.680088 & 19.184058 \\
32 & MALUKU UTARA & -5.69999 & 6.803976 \\
33 & PAPUA BARAT & 13.37639 & 25.88036 \\
34 & PAPUA & 16.86256 & 29.36653 \\
\hline
\end{tabular}

Source: processed data

Based on Table 4.5, it can be seen the constant values of each Province. The highest constant value is Papua Province at 29.36653, which means that it is related to the influence of zakat, infaq, and shadaqah (ZIS), gross regional domestic product, regional minimum wages and inflation on poverty levels, so the poverty level in Papua Province tends to be higher than other regions. Followed by West Papua Province with a constant value of 25,88036 . Then the third largest constant value is East Nusa Tenggara Province at 20.861439. The fourth largest constant value is Maluku Province with 19.184058. Moreover, the fifthlargest constant value is East Java Province at 19.078789.

While the lowest constant value is North Kalimantan Province which is 2.551436 which means it is related to the influence of zakat, infaq, and shadaqah (ZIS), gross regional domestic product, regional minimum wages and inflation on poverty levels, the poverty level in North Kalimantan Province tends to be lower compared to other regions. The second-lowest constant value is Bali Province, which is 4,55078, then South Kalimantan Province ranks third with a constant value of 4,765156. The fourth lowest constant value sequence is Kep. Bangka Belitung Province, which 
is 4.813413, then Central Kalimantan Province ranks fifth with a constant value of 5.704401 .

Beside analysis Random Effect Model based on each province, this study conducted a validity test of independent variables as summarized in Table 6 below.

\begin{tabular}{lrll}
\hline Variables & sig. t & Criteria & \multicolumn{1}{c}{ Conclusion } \\
\hline ZIS & 0.6936 & $>0,05$ & has no significant influence \\
GDRP & 0.0098 & $\leq 0,05$ & significant at $\alpha=0.05$ \\
RMW & 0.0162 & $\leq 0,05$ & significant at $\alpha=0.05$ \\
INF & 0.4986 & $>0,05$ & has no significant influence \\
\hline
\end{tabular}

Source: processed data

Table 6 depicts that regional gross domestic product and regional minimum wage individually variables have a significant effect on poverty levels while the variables of zakat, infaq, and shadaqah(ZIS) and inflation do not have a significant influence on poverty levels.

\section{Economic Interpretation}

Based on the cross section panel data estimation results show that the variables of zakat, infaq, and shadaqah have no significant effect on poverty levels in Indonesia in 2012-2016. This is not following the hypothesis that zakat, infaq, and shadaqah influence poverty levels in Indonesia.

Management of zakat, infaq, and shadaqah in several regions has notbeen carried outoptimally, so zakat, infaq, and shadaqah have not been able to alleviate poverty levels. Public awareness is not yet optimal toissueazakat,infaq, and sadaqahfor the poor(poorpeople).

\section{Gross Regional Domestic Product on Poverty Rate}

Based on the cross section panel data estimation results show that the gross regional domestic product variable has a negative and significant effect on poverty levels in Indonesia in 2012-2016.

The rate of economic growth is the increase in the regional gross domestic product (GRDP) regardless of whether the increase is large or small. Economic growth is not merely measured by 
overall GRDP growth, but also must pay attention to the extent of the distribution of income that has spread to all walks of life so that people can enjoy the results. If the distribution of income spreads evenly to all strata of society, the welfare of the community will increase and reduce poverty.

These results are consistent with research conducted by Rudi Masniadi et al. (2017), who said that gross regional domestic product had a negative and significant effect on poverty levels in West Sumbawa regency in 2008-2016.

\section{Regional Minimum Wage on Poverty Rate}

Based on the cross section panel data estimation results show that the regional minimum wage variable has a positive and significant effect on poverty levels in Indonesia in 2012-2016.

With the minimum wage, it will lift the degrees of the poor as wages increase, community welfare increases. If the welfare of the community increases, then the community is free from poverty. However, with the stipulation of the minimum wage must also pay attention to the extent to which the welfare of the community is achieved and whether the community has enjoyed the results of wages to meet their daily needs or not if the welfare of the community decreases, the level of poverty increases because the community cannot meet their needs.

These results are consistent with research conducted by Khairil Ihsan and Ikhsan (2018), who said regional minimum wages had a positive and significant effect on poverty levels in Aceh Province in 2008-2015.

\section{Inflation on Poverty Rate}

Based on the cross section panel data estimation results show that inflation does not have a significant effect on poverty levels in Indonesia in 2012-2016. This is consistent with the hypothesis that inflation does not influence poverty levels in Indonesia.

High inflation causes the purchasing power of people on low incomes to decline due to rising prices. So that the poor cannot fulfill their needs optimally because their purchasing power is under their income. 
These results are consistent with research conducted by Edyson Susanto et al. (2017), who said inflation was not significant for poverty in Samarinda City.

\section{CONCLUSION}

This paper concluded that the regional gross domestic product has a significant negative, and the regional minimum wage has a significant positive effect on the poverty level in Indonesia during 2012-2016. On Other hands, ZIS (Zakat, Infaq, and Sadaqah) and Inflation variables do not influence the poverty level. For further research, it is expected to analyze more variables, such unemployment rate to give a more in-depth understanding. Regional government should pay more attention in order to maximize the capability of Zakat, infaq, and Sadaqah to lower the poverty level.

\section{REFERENCES}

Abdussalam, O. I., Johari, F. and Alias, M. (2015) 'Is Zakah Effective to Alleviate Poverty in a Muslim Society?: A Case of Kwara State, Nigeria', Global Journal Al Thaqafah, 5(1), pp. 33-41. doi: 10.7187/gjat762015.05.01.

Alam, A. (2018) 'Analisis Efisiensi Pengelolaan Dana Zakat Infak Sedekah (Zis) Di Baznas Kabupaten/Kota SeKaresidenan Surakarta Dengan Menggunakan Metode Data Envelopment Analysis DEA', Iqtishoduna: Jurnal Ekonomi Islam, 7(2), pp. 262-290.

Andria, S., Hamzah, A. and Nasir, M. (2014) 'Faktor-faktor Yang Mempengaruhi Kemiskinan Relatif di Kota Banda Aceh', Jurnal Ilmu Ekonomi, 4(1).

Ayuniyyah, Q., Pramanik, A. H. and Ariffin, M. I. (2018) 'ZAKAT FOR POVERTY ALLEVIATION AND INCOME INEQUALITY REDUCTION : WEST JAVA, INDONESIA', Journal of Islamic Monetary Economics and Finance, 4(1), pp. 85-100.

Canggih, C., Fikriyah, K. and Yasin, A. (2017) 'Potensi Dan Realisasi Dana Zakat Indonesia', al-Uqud: Journal of 
Islamic Economics, 1(1), p. 14. doi: 10.26740/jie.v1n1.p1426.

Hamidah, R. A. et al. (2017) 'Impact of ZIS (Zakah, Infaq, and Sadaqa ) Distribution and Islamic Financial Institutions to MSMEs (Micro, Small, and Medium Enterprises ) and Gross Regional Product Growth in East Java ( 2011-2014 Periods )', 1(1).

Hamrolle, H. (2004) Analisis Peningkatan PAD. Yogyakarta: BPFE-YOGYAKARTA.

Hassanain, K. M. A. (2017) 'Zakah for Poverty Alleviation : Evidence from Sudan' (January 2016).

Ihsan, K. and Ikshan (2018) 'Analisis pengaruh ump, inflasi dan pengangguran terhadap kemiskinan di provinsi aceh', 3(3), pp. 408-419.

Kareem, M. K., and Bankole, A. S. (2016) 'Zakah, Poverty Alleviation, and Inclusive Growth in Nigeria', Journal of Islamic Finance, 5(2), pp. 53-65.

Kasri, R. A. (2016) 'Effectiveness of Zakah Targeting in Alleviating Poverty in Indonesia', Al-Iqtishad: Journal of Islamic Economics, 8(2), pp. 169-186. doi: 10.15408/aiq. v8i2.3005.

Kasri, R. A. (2017) 'International journal of Islamic economics and finance studies,' pp. 30-40. doi: 10.25272/j.21498407.2017.3.3.03.

Mahendra (2016) 'Analisis Pengaruh Pertumbuhan Ekonomi Pendapatan Perkapita, Inflasi Dan Pengangguran Terhadap Jumlah Penduduk Miskin Di Provinsi Sumatera Utara', JRAK, 2(2), pp. 123-148.

Maipita, I. (2012) Mengukur Kemiskinandan Distribusi Pendapatan. Yogyakarta: UPP STIM YKPN.

Maipita, I. (2014) Mengukur Kemiskinan Dan Distribusi Pendapatan. Yogyakarta. Yogyakarta: UPP STIM YKPN.

Ningrum, S. S. (2017) 'Analisis Pengaruh Tingkat Pengangguran Terbuka, Indeks Pembangunan Manusia, dan Upah 
Minimum Terhadap Jumlah Penduduk Miskin Di Indonesia Tahun 2011-2015', Jurnal Ekonomi Pembangunan, 15(2), pp. 185-192.

Sari, J. and Mangkuwinata, D. S. (2017) 'Pengaruh Variabel Makro Ekonomi Terhadap Kemiskinan Di Provinsi Aceh', JURNAL EKONOMI DAN BISNIS, 18(2), pp. 94-107.

Sudiana, I. W. and Sudiana, I. ketut (2015) 'Pengaruh Pdrb, Pendidikan Dan Struktur Tenaga Kerja Terhadap Kemiskinan Di Provinsi Bali', e-Jurnal Ekonomi Pembangunan Universitas Udayana, 4(6), pp. 608-620.

Sukirno, S. (2008) Makro Ekonomi Teori Pengantar. Jakarta: PT Raja Grafindo Jakarta.

Susanto, E., Rochaida, E. and Ulfah, Y. (2018) 'Pengaruh inflasi dan pendidikan terhadap pengangguran dan kemiskinan', Inovasi, 13(1), p. 19. doi: 10.29264/jinv.v13i1.2435. 